\title{
Effect of Prone Position versus Diaphragmatic Release in Patients with COPD in ICU
}

\author{
ISAAC Z. ZARII, M.Sc.*; SAMIR A. EL GAZAR, Ph.D.*; YOUSSEF M. AMIN SOLIMAN, M.D.** and \\ NAGY L. NASSIF, Ph.D.*
}

The Department of Cardiovascular/Respiratory Disorder and Geriatrics, Faculty of Physical Therapy* and

The Department of Pulmonology, Faculty of Medicine**, Cairo University

\begin{abstract}
Background: Chronic Obstructive Pulmonary Disease (COPD) is a major health problem characterized by chronic airflow limitation that is usually progressive and is associated with an abnormal inflammatory response of the lungs to noxious particles or gases, primarily caused by cigarette smoking.

Aim of Study: This study was carried out to compare the therapeutic effect of prone position versus diaphragmatic release in patients with COPD in ICU.

Patients and Methods: Sixty patients with COPD were randomly assigned into two equal groups. The methods of assessment included Acid-base analyzer. Group (A) lied in prone position, for one hour for five consecutive days while Group (B) received diaphragmatic release technique for five consecutive days.

Results: The results showed that there was significant increase in $\mathrm{PaO}_{2}$ and $\mathrm{O}_{2}$ Sat in second group compared to the first group. In relation to $\mathrm{ABG}$ results and $\mathrm{O}_{2} \mathrm{Sat}$. The study revealed that the results obtained in second group were superior to that of first group.

Conclusion: It was concluded that diaphragmatic release technique superior to prone position in treatment of COPD in ICU.
\end{abstract}

Key Words: COPD, Diaphragmatic release - Prone position - Acid-Base analyzer.

\section{Introduction}

COPD is a chronic disease of the airways with high morbidity, mortality and poor quality of patients' life. It is currently the fourth leading cause of death in the world but is projected to be the third leading cause of death by 2020 [1,2].

In patients with COPD there is an acute worsening of respiratory symptoms with significant

Correspondence to: Dr. Isaac Z. Zarii, The Department of Cardiovascular/Respiratory Disorder and Geriatrics, Faculty of Physical Therapy, Cairo University increase in morbidity and mortality. These signs and symptoms are increase dyspnea, productive cough, mucus hyper secretion, reduced expiratory flow, hyperinflation and impaired lung function due to increase airway thickening and increase intraluminal mucus secretion [2].

In COPD, changes in the anatomy of the airways and lung parenchyma occur as the result of bronchial hyper secretion and Broncho alveolar instability. These changes cause expiratory flow limitation and air trapping, known clinically as dynamic hyperinflation. This phenomenon leads to increases in expiratory reserve volume, Residual Volume $(\mathrm{RV})$ and end expiratory lung volume (EEV). The increase in EEV limits tidal and inspiratory reserve volumes resulting in a negative impact on Inspiratory Capacity (IC). These changes alter the position of the ribs causing a state similar to sustained inspiration over time, often referred to as "inspiratory block". This phenomenon is responsible for the characteristic "barrel chest" commonly seen in patients with COPD. In this state, the position of the diaphragm is flattened and shortened reducing its ability to generate force [3].

The significant physiological effects of the prone position are: Changes of the respiratory mechanics, and ventilation induced lung injury, They may lead to the homogenization of pulmonary gas exchange, a reduction of ventilation-perfusion mismatch, and increase of lung volume involved in gas exchange due to a reduction of marginally or non-ventilated areas (atelectasis) and to a reduction of ventilation-associated lung injury. The assumption is made that an improvement of the drainage of Broncho alveolar secretion is affected [4]. 
The diaphragmatic release technique is the application of a low load, long duration, optimal length of this stretch into the myofascial complex, with the aim to restore the complex [5].

Release Technique improves diaphragmatic mobility, The Manual Diaphragm exercise capacity and inspiratory capacity in people with chronic obstructive pulmonary disease. This technique could be considered in the management of people with chronic obstructive pulmonary disease [3].

\section{Patients and Methods}

Sixty patients had been recruited from Intensive Care Unit (ICU), of Kasr El-Ainy Hospitals during 2019. They were diagnosed as Chronic Obstructive Pulmonary Diseases (COPD), stage III, by specialized physician. They received medical treatment and oxygen therapy.

Sixty patients of both sexes, their age ranged from (50-60 year). They suffered from COPD. They suffered from dyspnea, chronic cough and expectorations, with Forced Expiratory Volume in one second $\left(\mathrm{FEV}_{1} \mathrm{sec}\right)$ less than $70 \%$ of predicted value. All patients suffered from tachypnea where the respiratory rate ranged from (22 to 28) Brpm, severe hypoxemia where $\mathrm{PaO}_{2}$ ranged from (29 to 73) $\mathrm{mmHg}$ and $\mathrm{PaCO} 2$ ranged from (24 to 94$)$ $\mathrm{mmHg}$. The duration of mechanical ventilation ranged from (2-5) days.

Patients were randomly subdivided into two equal groups, each group consisted of 30 patients, group (A) placed in prone lying position. And group (B) received diaphragmatic release.

\section{Exclusion criteria:}

Patients with the following criteria will excluded from the study:

1- Severe psychiatric or cognitive impairments.

2- Progressive neuromuscular disorders.

3- Decreased level of consciousness.

4- Unstable fracture.

5- Pacemaker inserted for fewer than 2 days.

6- Deep-venous thrombosis (to minimize risk for pulmonary embolism from being in a prone position.

7- Mean arterial blood pressure of less than $65 \mathrm{~mm}$ $\mathrm{Hg}$ with or without vasopressors.

8- Tracheal surgery or sternotomy in the last 15 days.

9- Massive haemoptysis.
10- Intracranial pressure of more than $30 \mathrm{mmHg}$ or cerebral perfusion pressure of less than $60 \mathrm{mmHg}$.

\section{Equipment and tools:}

All patients were assessed by Blood-Gas analyzer at the beginning of the session and after session for 5 consecutive days.

\section{Treatment procedures:}

- Group A: Included 30 patients who receive:

1- Medical treatment; all patients received their regular prescriptive treatment in the form of bronchodilator and mucolytic.

The first sample was drawn at baseline supine position.

2- Prone lying position: In this position the patient's head was turned laterally and the arms parallel to the body. A roll was placed under the upper part of chest wall, and a pillow was placed under the pelvis to minimize the restriction of abdomen movement. Every patient was kept in this position for one hour. Then the blood sample was drawn, and then every patient returned to the supine lying position.

- Group B: Included 30 patients who receive:

1- Medical treatment: All patients received their regular prescriptive treatment in the form of bronchodilator and mucolytic.

The second sample was drawn before the application of technique.

2- Diaphragmatic release: The therapist palpated the fascial restriction and the pressure was applied directly to the skin, into the direction of the restriction, until resistance (the tissue barrier) was manually perceived. Once found, the collagenous barrier was engaged for a few minutes, without sliding over the skin or forcing the tissue, until the band started to yield the complex and a sensation of softening was achieved. Then draw the blood sample.

\section{Statistical analysis:}

Descriptive statistics and $t$-test were conducted for comparison of the mean age, weight and height between both groups.

Unpaired $t$-test was conducted for comparison of $\mathrm{PaO}_{2}$ and $\mathrm{SaO}_{2}$ between both groups.

Paired $t$-test was conducted for comparison between pre and post-treatment $\mathrm{PaO}_{2}$ and $\mathrm{SaO}_{2}$ in each group. 
The level of significance for all statistical tests was set at $p<0.05$.

All statistical measures were performed through the Statistical Package for Social Studies (SPSS) version 25 for windows.

\section{Results}

\section{General characteristics of the subjects:}

- Group A: Thirty patients with COPD were included in this group. Their mean \pm SD age, weight and height were $56.03 \pm 3.04$ years, $80.43 \pm 10.41 \mathrm{~kg}$ and $170.5 \pm 7.91 \mathrm{~cm}$ respectively (Table 1).

- Group B: Thirty patients with COPD were included in this group. Their mean \pm SD age, weight and height were $55.56 \pm 3.63$ years, $78.4 \pm 9.28 \mathrm{~kg}$ and $171.13 \pm 7.78 \mathrm{~cm}$ respectively (Table 1 ).

Comparing the general characteristics of the subjects of both groups revealed that there was no significance difference between both groups in the mean age weight and height $(p>0.05)$.

Table (1): Comparison of the mean age, weight and height between group $\mathrm{A}$ and $\mathrm{B}$.

\begin{tabular}{|c|c|c|c|c|c|c|}
\hline & $\begin{array}{l}\text { Group A } \\
X \pm S D\end{array}$ & $\begin{array}{l}\text { Group B } \\
X \pm S D\end{array}$ & MD & $\begin{array}{c}t- \\
\text { value }\end{array}$ & $\begin{array}{c}p- \\
\text { value }\end{array}$ & Sig. \\
\hline Age (years) & $56.03 \pm 3.04$ & $55.56 \pm 3.63$ & 0.47 & 0.53 & 0.59 & NS \\
\hline Weight (kg) & $80.43 \pm 10.41$ & $78.4 \pm 9.28$ & 2.03 & 0.79 & 0.42 & NS \\
\hline Height $(\mathrm{cm})$ & $170.5 \pm 7.91$ & $171.13 \pm 7.78$ & -0.63 & -0.31 & 0.75 & NS \\
\hline
\end{tabular}

$\mathrm{PaO}_{2}$ :

\section{I- Between groups comparison:}

Pre-treatment: The mean $\pm \mathrm{SD} \mathrm{PaO}_{2}$ pretreatment of the group A was $60.03 \pm 3.16 \mathrm{mmHg}$ and that of the group B was $59.3 \pm 2.96 \mathrm{mmHg}$. The mean difference between both groups was 0.73 $\mathrm{mmHg}$. There was no significant difference in $\mathrm{PaO}_{2}$ between the group $\mathrm{A}$ and $\mathrm{B}$ pretreatment $(p=$ 0.35 ) (Table 2).

Post-treatment: The mean $\pm \mathrm{SD} \mathrm{PaO}_{2}$ posttreatment of the group A was $64.4 \pm 3.11 \mathrm{mmHg}$ and that of the group B was $76.3 \pm 3.61 \mathrm{mmHg}$. The mean difference between both groups was -11.9 $\mathrm{mmHg}$. There was a significant increase in $\mathrm{PaO}_{2}$ of the group $\mathrm{B}$ compared with that of the group $\mathrm{A}$ post-treatment ( $p=0.0001)$ (Table 2$)$.

Table (2): Comparison of pre and post-treatment mean values of $\mathrm{PaO}_{2}$ between group $\mathrm{A}$ and $\mathrm{B}$.

\begin{tabular}{|c|c|c|c|c|}
\hline \multirow{2}{*}{$\begin{array}{l}\mathrm{PaO}_{2} \\
(\mathrm{mmHg})\end{array}$} & \multicolumn{2}{|c|}{ Pre-treatment } & \multicolumn{2}{|c|}{ Post-treatment } \\
\hline & Group A & Group B & Group A & Group B \\
\hline \multirow{5}{*}{$\begin{array}{l}\mathrm{X} \pm \mathrm{SD} \\
\mathrm{MD} \\
t \text {-value } \\
p \text {-value } \\
\text { Significance }\end{array}$} & \multicolumn{2}{|c|}{$60.03 \pm 3.16 \quad 59.3 \pm 2.96$} & \multicolumn{2}{|c|}{$64.4 \pm 3.11 \quad 76.3 \pm 3.61$} \\
\hline & \multicolumn{2}{|c|}{0.73} & \multicolumn{2}{|c|}{-11.9} \\
\hline & \multicolumn{2}{|c|}{0.92} & \multicolumn{2}{|c|}{-13.66} \\
\hline & \multicolumn{2}{|c|}{0.35} & \multicolumn{2}{|c|}{0.0001} \\
\hline & \multicolumn{2}{|c|}{ NS } & \multicolumn{2}{|c|}{ S } \\
\hline Mean & \multicolumn{4}{|c|}{ Mean. } \\
\hline \multicolumn{5}{|c|}{ Mean Difference. } \\
\hline \multicolumn{5}{|c|}{$p$-value : Probability value. } \\
\hline SD : Stand & \multicolumn{4}{|c|}{ : Standard Deviation. } \\
\hline$t$-value : Unpai & \multicolumn{4}{|c|}{ : Unpaired $t$-value. } \\
\hline NS : Non S & \multicolumn{4}{|c|}{ : Non Significant. } \\
\hline \multicolumn{5}{|c|}{ : Significant. } \\
\hline
\end{tabular}

\section{II- Within groups comparison:}

Group A: The mean $\pm \mathrm{SD} \mathrm{PaO}_{2}$ pre-treatment of the group A was $60.03 \pm 3.16 \mathrm{mmHg}$ and that post-treatment was $64.4 \pm 3.11 \mathrm{mmHg}$. The mean difference between pre and post-treatment was $-4.37 \mathrm{mmHg}$ and the percent of improvement was $7.28 \%$. There was a significant increase in $\mathrm{PaO}_{2}$ of the group A post-treatment compared with that pre-treatment $(p=0.0001)$ (Table 3$)$.

Group B: The mean $\pm \mathrm{SD} \mathrm{PaO}_{2}$ pre-treatment of the group B was $59.3 \pm 2.96 \mathrm{mmHg}$ and that posttreatment was $76.3 \pm 3.61 \mathrm{mmHg}$. The mean difference between pre and post-treatment was $-17 \mathrm{mmHg}$ and the percent of improvement was $28.67 \%$. There was a significant increase in $\mathrm{PaO}_{2}$ of the group $\mathrm{B}$ post-treatment compared with that pre-treatment $(p=0.0001)$ (Table 3).

Table (3): Comparison between pre and post-treatment mean values of $\mathrm{PaO}_{2}$ of the group $\mathrm{A}$ and $\mathrm{B}$.

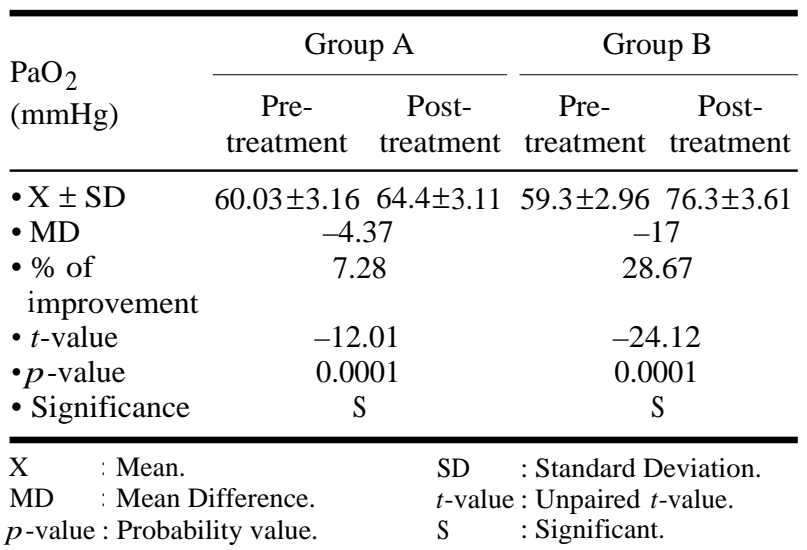


$\mathrm{SaO}_{2}$ :

I- Between groups comparison:

Pre-treatment: The mean $\pm \mathrm{SD} \mathrm{SaO}_{2}$ pretreatment of the group A was $89.1 \pm 2.52 \%$ and that of the group B was $88.53 \pm 2.71 \%$. The mean difference between both groups was $0.57 \%$. There was no significant difference in $\mathrm{SaO}_{2}$ between the group $\mathrm{A}$ and $\mathrm{B}$ pre-treatment $(p=0.4)$ (Table 4).

Post-treatment: The mean $\pm \mathrm{SD} \mathrm{SaO}_{2}$ posttreatment of the group A was $92.33 \pm 2.41 \%$ and that of the group B was $96.2 \pm 2.6 \%$. The mean difference between both groups was $-3.87 \%$. There was a significant increase in $\mathrm{SaO}_{2}$ of the group $\mathrm{B}$ compared with that of the group A post-treatment $(p=0.0001)$ (Table 4).

Table (4): Comparison of pre and post-treatment mean values of $\mathrm{SaO}_{2}$ between group $\mathrm{A}$ and $\mathrm{B}$ :

\begin{tabular}{|c|c|c|c|c|}
\hline \multirow{2}{*}{$\mathrm{SaO}_{2}(\%)$} & \multicolumn{2}{|c|}{ Pre-treatment } & \multicolumn{2}{|c|}{ Post-treatment } \\
\hline & Group A & Group B & Group A & Group B \\
\hline $\mathrm{X} \pm \mathrm{SD}$ & $89.1 \pm 2.52$ & $88.53 \pm 2.71$ & $92.33 \pm 2.41$ & $96.2 \pm 2.6$ \\
\hline MD & & .57 & -3.8 & \\
\hline$t$-value & & 83 & $-5 . \mathrm{C}$ & \\
\hline$p$-value & & .4 & 0.00 & \\
\hline Significance & & vS & S & \\
\hline $\begin{array}{l}\mathrm{X} \\
\mathrm{MD}: \text { Mean } \\
p \text {-value }: \text { Proba } \\
\text { SD }: \text { Stand }\end{array}$ & $\begin{array}{l}\text { Difference. } \\
\text { bility value. } \\
\text { lard Deviation }\end{array}$ & $\begin{array}{l}t-\mathrm{v} \\
\mathrm{NS} \\
\mathrm{S}\end{array}$ & \multicolumn{2}{|c|}{$\begin{array}{l}\text {-value : Unpaired } t \text {-value. } \\
\text { IS } \quad \text { Non Significant. } \\
\quad \text { Significant. }\end{array}$} \\
\hline
\end{tabular}

\section{II- Within groups comparison:}

Group A: The mean $\pm \mathrm{SD} \mathrm{SaO}_{2}$ pre-treatment of the group A was $89.1 \pm 2.52 \%$ and that posttreatment was $92.33 \pm 2.41 \%$. The mean difference between pre and post-treatment was $3.23 \%$ and the percent of improvement was $3.63 \%$. There was a significant increase in $\mathrm{SaO}_{2}$ of the group A posttreatment compared with that pre-treatment $(p=$ 0.0001) (Table 5).

Group B: The mean $\pm \mathrm{SD} \mathrm{SaO}_{2}$ pre-treatment of the group B was $88.53 \pm 2.71 \%$ and that posttreatment was $96.2 \pm 2.6 \%$. The mean difference between pre and post-treatment was $-7.67 \%$ and the percent of improvement was $8.66 \%$. There was a significant increase in $\mathrm{SaO}_{2}$ of the group B posttreatment compared with that pre-treatment $(p=$ 0.0001) (Table 5).
Table (5): Comparison between pre and post-treatment mean values of $\mathrm{SaO}_{2}$ of the group $\mathrm{A}$ and $\mathrm{B}$.

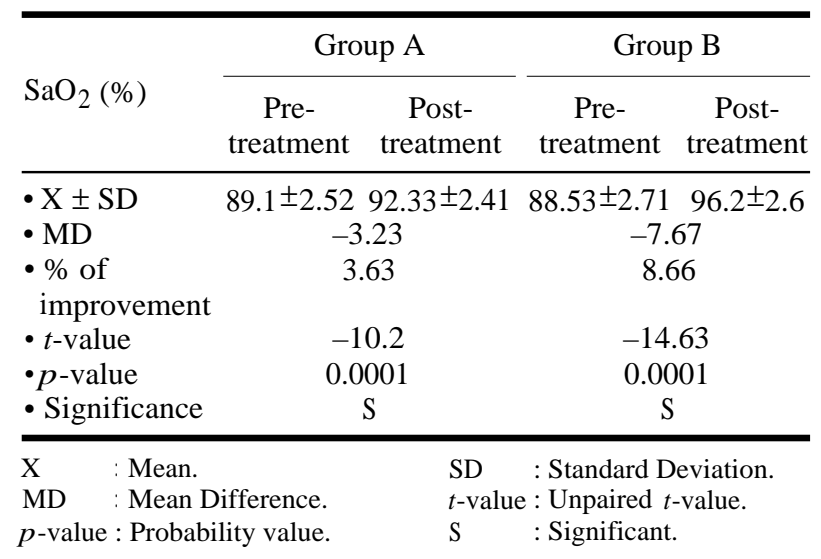

\section{Discussion}

This study was designed to compare the efficacy of diaphragmatic release versus prone position on improving oxygenation and ventilation in patients with COPD.

Sixty patients with Chronic Obstructive Pulmonary Disease (COPD) were included in this study. All patients assigned randomly into two groups of 30 patients in each group. (Group A): Was enrolled in prone position protocol in addition to traditional physical therapy program for COPD. (Group B): Was enrolled in diaphragmatic release protocol in addition to traditional physical therapy protocol. The treatment sessions applied 5 consecutive days.

Blood Gas analyser used to measure arterial blood gases and to evaluate the level of oxygenation and saturation $\left(\mathrm{PaO}_{2}, \mathrm{SaO}_{2}\right)$ for all patients participated in this study pre-session and post-session.

There was significant difference between first and second group in $\mathrm{ABG}$ results post-treatment sessions in favor of second group.

Results of this study concerning the effect of prone position versus diaphragmatic release in patients with COPD confirmed the observations of studies done by:

\section{Group (A): Prone position:}

Pronation of severe chronic bronchitis patients reduces airway resistance and attenuates dynamic hyperinflation. This is probably attributable to improved parenchyma mechanics inducing an increase in airway calibre during the respiratory cycle [6].

Prone position has been shown to result in a short-term gain in oxygenation, and improvement of ventilation and perfusion mismatch and residual 
lung capacity, despite their physiological rationale, these easy-to-apply techniques are still not widely used and it is still unclear [7]

On the other hand, in a study on 16 patients with severe degree of COPD concluded that there was no significant change between prone position and supine position regarding respiratory system static compliance. He refers to the fact that limited movement in chest wall secondary to limitation of the sternal movement decreases the lung compliance and concluded that when returning to the supine position oxygenation slightly declined, but no significant differences were observed when compared with baseline or the prone position; but they also commented "because of the small population, we cannot exclude a type II error. Once again, these average values were derived from variable individual responses. Different oxygenation responses when returning to the supine position have been previously described, including both a reversal of oxygenation improvement and a maintenance of improved oxygenation" [8].

In addition, a study on 30 patients with acute on top of chronic respiratory failure due to chronic obstructive pulmonary disease. Patients were subjected to volume controlled, pressure controlled, and pressure support in three different positions: Supine, semi setting and prone, they concluded that there was no significant difference in static compliance between prone and supine position [9]

Group (B): Diaphragmatic release. In agreement with the results of the current study, Carlos, made a study consisted of twelve medically stable patients $(n=12)$ with an existing diagnosis of severe COPD (ten: GOLD Stage III and two: GOLD Stage IV) were included. Residual volume, inspiratory capacity and oxygen saturation $\left(\mathrm{SpO}_{2}\right)$ were recorded immediately before and after administration of the STMTP. Residual volume decreased from 4.5 to $3.9 \mathrm{~L}(p=0.002)$, inspiratory capacity increased from 2.0 to $2.1 \mathrm{~L}(p=0.039)$ and $\mathrm{SpO}_{2}$ increased from $93 \%$ to $96 \%$ ( $p=0.001)$. So it was concluded that a single application of soft tissue manual therapy intervention appears to have the potential to produce immediate clinically meaningful improvement in the lung function in patients with severe and very severe COPD [10].

Combining manual therapy with exercise appears to increase the respiratory function of normal individuals. The potential for this intervention administered before exercise to permit additional tolerance within the respiratory system that could allow an extended exercise program [12]
In addition, diaphragm release technique generated a significant improvement in posterior chain muscle kinematics measured by schober's test, the finger to floor test, cervical range of motion, and rib cage excursion at xiphoid level immediately after technique.

Against to Donald, who determine that individual manipulation techniques were associated with a modest post-treatment worsening of pulmonary function measures in persons with COPD Overall, the techniques tested worsened pulmonary function at thirty minutes post-treatment in persons with COPD. The longer term effects of these techniques on pulmonary function are still not known. Despite adverse changes in pulmonary function measures, the majority of COPD patients subjectively reported they benefitted from manual techniques and they could breathe better after receiving the manual techniques [12].

Twenty adults aged over 60 years with clinically stable chronic obstructive pulmonary disease. The group received six treatments with the Manual Diaphragm Release Technique on non-consecutive days within a 2 -week period. The main outcome was diaphragmatic mobility, which was analysed using ultrasonography. Outcomes were measured before and after the first and sixth treatments. The Manual Diaphragm Release Technique significantly improved diaphragmatic mobility over the course of treatments, The Manual Diaphragm Release Technique improves diaphragmatic mobility, exercise capacity and inspiratory capacity in people with chronic obstructive pulmonary disease. This technique could be considered in the management of people with chronic obstructive pulmonary disease [3]

Muralimohan, applied a study in which the sample size is 15 patients, 45 minutes of each session 4 sessions per week for 6 weeks. The result showed the subjects who received Manual Diaphragmatic Release Technique along with Yogic breathing practice are found to be more effective in improving diaphragm mobility, inspiratory capacity and exercise tolerance in COPD patients. It was concluded that, modern manual diaphragmatic release technique and Yogic breathing technique (yogic breathing practice) gives more effect in improving diaphragm mobility, inspiratory capacity and exercise tolerance in COPD patients [13]

Also Susmitha made a study consists of 30 subjects with chronic obstructive pulmonary disease were selected by random sampling method and were divided into 2 groups namely Group-A and 
Group-B respectively. Group-A subjects were involved in Manual Diaphragmatic Release technique and Group-B Subjects performed conventional diaphragmatic strengthening exercises. Study was conducted for a period of three month. The result shows that the subjects in Group A shown a marked improvement in Diaphragmatic Mobility and Exercise capacity when compared with the subjects in Group B. This study concluded that the Manual Diaphragmatic release techniques shows superior improvement in diaphragmatic mobility and exercise capacity in subjects with COPD [14].

As observed in the results of this present study, group (B) diaphragmatic release group, showed a statistical significant improvement in oxygenation and ventilatory functions that was more than the improvement in group (A) prone position group.

\section{References}

1- GOLD: Global Initiative for Chronic Obstructive Lung Disease: "Global strategy for the diagnosis, management and prevention of chronic obstructive pulmonary disease" 2018.

2- CURRIE G.: ABC of COPD. ( $2^{\mathrm{nd}}$ ed) Chapter 1, Page 1$5,2017$.

3- ROCHA T., SOUZA H., BRANDÃO D., RATTES C., RIBEIRO L., CAMPOS S. and ALIVERTI A.: "The Manual Diaphragm Release Technique improves diaphragmatic mobility, inspiratory capacity and exercise capacity in people with chronic obstructive pulmonary disease: A randomised trial". Journal of Physiotherapy, 61 (4): 1829, 2015.

4- BEIN H., BISCHOF M., BRÜCKNER U., GEBHARDT K., HENZLER D. and HERMES C.: "S2e guideline: Positioning and early mobilization in prophylaxis or therapy of pulmonary disorders". Der Anaesthesist, 64 (1): $1-26,2015$

5- BRUNO C. and VALENTI M.: "Acid -base disorders in patients with chronic obstructive pulmonary disease: A Pathophysiological review .Journal of biomedicine and biotechnology: 1-8, 2016.
6- MENTZELOPOULOS S., ROUSSOS C. and ZAKYNTHINOS S.: " Prone position improves expiratory airway mechanics in severe chronic bronchitis", Eur. Respir. J., 25: 259-68, 2005

7- AMBROSINO N., VENTURELLI E., VAGHEGGINI G. and CLINI E.: "Rehabilitation, weaning and physical therapy strategies in chronic critically ill patients." European Respiratory Journal, 39: 487-92, 2012.

8- PELOSI P., TUBIOLO D. and MASCHERONI D.: "Effects of the prone position on respiratory mechanics and gasexchange during acute lung injury." Am. J. Respir. Crit. Care Med., 157: 387-93, 2004.

9- MASOUD H., EL-HOSIENY A., SABRY E., and ESMAT A.: "Variation in pulmonary mechanics and blood gases parameters due to postural changes in mechanically ventilated COPD patient on different Ventilatory modes". Egyptian Journal of Chest Disease and Tuberculosis, 51: (2): 109, 2002.

10- CARLOS C., DIEGO G., FELIPE A., PAULINA G., LEANDRO M. VENEGAS and ROGER M.: "The immediate effect of soft tissue manual therapy intervention on lung function in severe chronic obstructive pulmonary disease". Int. J. Chron. Obstruct. Pulmon. Dis., 12: 6916, 2017.

11- ROGER M. and ENGEL D.: "The Effect of Combining Manual Therapy with Exercise on the Respiratory Function of Normal Individuals: A Randomized Control Trial ". Journal of Manipulative and Physiological Therapeutics, 30 (7): 509-13, 2007

12- DONALD R., BRIAN F., JANE C. and SELINA A. "Immediate Effects of Osteopathic Manipulative Treatment in Elderly Patients With Chronic Obstructive Pulmonary Disease" J. Am. Osteopath Assoc., 20: (1-2): 16-22, 2009.

13- MURALIMOHAN R.: "Effectiveness of manual diaphragmatic release techniques slong with yogic breathing practice on improving diaphragm mobility, inspiratory capacity and exercise tolerance in COPD patients" Nandha college of physiotherapy, 2019.

14- SUSMITHA P.: "The effect of manual diaphragmatic release techniques in the improvement of diaphragm mobility and exercise capacity in subjects with chronic obstructive pulmonary disease". Nandha college of physiotherapy, 2017. 


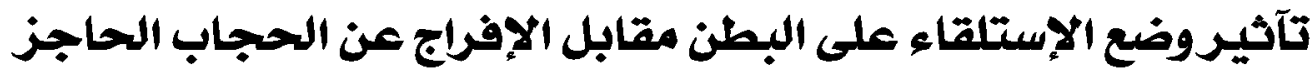

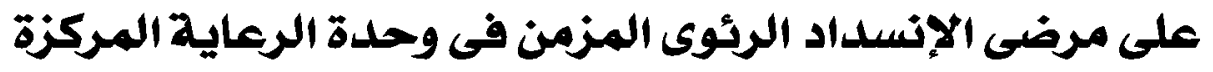

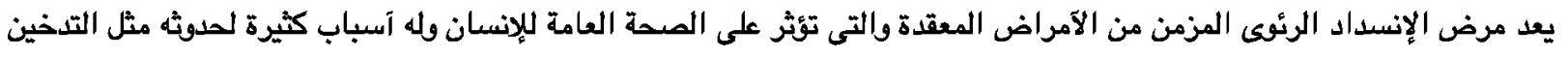

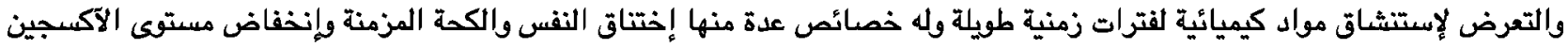

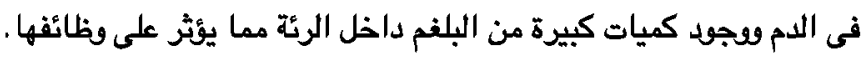

صممت هذه الرسالة للمقارنة بين وسيلتين فعاليتين فى علاج هذا المرض لمعرفة ما هو آكثر فاعلية فى علاج الإنسداد الرئوى المزمن اثثاء تطوده الحاد في وحدة الرعاية المركزة.

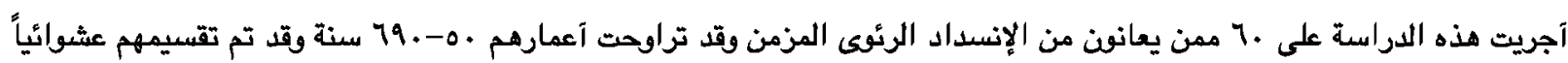
إلى مجموعتين متساويتين فى العدد:

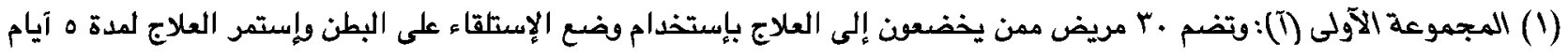
متتالية.

(r) المجموعة الثانية (ب): وتتكون من ·r مريض ممن يلقون الإفراج عن الحجاب الحاجز وإستمر العلاج لمدة ه آيام متتالية. تم التقييم بإستخدام طريقتين التقييم قبل بدء الجلسة وبعد نهايتها: قياس نسبة الآكسجين فى الدم وقياس درجة تثبع الدم بالآكسجين. ويستتج من هذا البحث آن هناك تحسن ملحوظ فى نسبة الاكسجين ودرجة تثبع الدم هنه بعد ه آيام متتالية من العلاج لكل المرضى فى المجموعتين.

آن هناك زيادة ذو دلالة إحصائية فى نسبة الآكسجين ودرجة تثبع الدم منه بعد ه آيام متتالية فى المجموعة (ب). آن هناك فرقق ذات دلالة إحصائية بين المجموعتين (المجموعة الآولى والمجموعة الثانية) . وكانت آفضل النتائج بالنسبة إلى نسبة الاكسجين ودرجة تثبع الدم هنه فى المجموعة الثانية. 